\title{
Dampak Transaksi Pembayaran Go-Pay Bagi Peningkatan Penjualan Pedagang Kecil Menengah di Pasar Modern BSD
}

\author{
Ani Rakhmanita ${ }^{1}$, Desy Tri Anggarini ${ }^{2}$ \\ 1,2 Universitas Bina Sarana Informatia \\ e-mail: 19ani.ark@bsi.ac.id, ${ }^{2}$ desy.dra@bsi.ac.id
}

\begin{abstract}
Abstrak - Penelitian ini dilakukan dengan dilatar belakangi maraknya penggunaan pembayaran uang virtual yaitu Go-Pay. Fintech merubah cara manusia menggunakan jasa layanan keuangan, yang semula transaksi pelayanan keuangan dilakukan dengan pembayaran sejumlah uang kas. Fintech menjadi sangat penting dan membantu mengerakkan roda perekonomian yang produktif serta dapat mengembangkan Usaha kecil Menengah. Data yang terdapat di laman Go-Jek, tahun 2018 terdapat lebih dari 420.000 rekan usaha, 90\% rekan usaha tersebut merupakan pengusaha kecil yang telah menerapkan pembayaran dengan uang virtual. Penelitian ini bermaksud mengetahui dampak perubahan transaksi pembayaran virtual usaha kecil menengah, yaitu pedagang kecil menengah selaku mitra GoPay tertarik menerima pembayaran dengan uang virtual (GoPay) dan pengaruh dari pembayaran uang virtual terhadap tingkat penjualan pedagang kecil menengah. Objek dalam penelitian ini adalah pedagang kecil menengah di Pasar Modern BSD. Pemilihan lokasi ini diambil dikarenakan sebagai area penggunaan transaksi pembayaran Go-Pay terbanyak di pasar modern di Tangerang. Metode penelitian yang digunakan pada penelitian ini, yaitu kualitatif dengan analisis kualitatif deskriptif. Teknik pengumpulan data dilakukan dengan wawancara kelima pedagang kecil yg telah mengunakan pembayaran Go-Pay. Penelitian ini bertujuan untuk megetahui dampak pengunaan transaksi pembayaran Go-pay terhadap peningkatan penjualan pedagang kaki lima di Pasar Modern BSD. Diperoleh hasil bahwa pengunaan transaksi pembayaran Go-pay berdampak terhadap peningkatan penjualan.
\end{abstract}

Kata kunci : Go-Pay, uang virtual, penjualan, financial technology, fintech

Abstract - This research was carried out against the background of the widespread use of virtual payments, namely Go-Pay. Fintech changed the way humans used financial services, which were originally financial service transactions carried out by payment of cash. Fintech becomes very important and helps move of a productive economy and can develop small and medium bussiness. The data contained in the Go-Jek page, in 2018 there were more than 420,000 business partners, 90\% of these business partners were small entrepreneurs who had implemented payments with virtual money. This study intends to determine the impact of changes in virtual small and medium business payment transactions, a small and medium traders as GoPay partners interested in receiving payments with virtual money (GoPay) and the effect of virtual money payments on the level of sales of small and medium traders. The object of this research is small and medium traders in the Modern Market BSD. The choice of location was taken because it is the most widely used area for Go-Pay payment transactions in the modern market in Tangerang. The research method used in this study, qualitative with descriptive qualitative analysis. The data collection technique was carried out by interviewing five small traders who had used Go-Pay payments. This study aims to determine the impact of the use of Go-pay payment transactions to increase sales of street vendors in BSD Modern Market. The results show that the use of Go-pay payment transactions has an impact on increasing sales.

Keywords: Go-Pay, virtual money, sales, financial technology, fintech

\section{PENDAHULUAN}

Pergerakan bisnis di era revolusi 4.0 disertai dengan berkembangnya teknologi yang mutakhir dan infrastruktur komunikasi yang stabil. Hal ini menyebabkan banyaknya inovasi-inovasi terbaru dalam sektor keuangan. Salah satu inovasi tersebut adalah financial technology (FinTech). Menurut Bank Indonesia, Financial technology merupakan inovasi pengabungan antara teknologi modern dengan jasa layanan keuangan secara efisien. Fintech merubah cara manusia menggunakan jasa layanan keuangan, yang semula transaksi pelayanan keuangan dilakukan dengan pembayaran sejumlah uang kas, kini dapat dilakukan dengan cara yang lebih praktis, mengunakan uang virtual (https://www.bi.go.id/)] FinTech di Indonesia memiliki beberapa layanan dan produk yang dapat dimanfaatkan oleh masyarakat. Bank Indonesia membaginya menjadi beberapa jenis, diantaranya yaitu platform online untuk pinjaman atau kredit, gadai, aplikasi pembayaran, platform online untuk mengumpulkan donasi dan bantuan, 
perencanaan keuangan, pasar modal, layanan internet banking dan asuransi. Layanan produk yang berkembang di Indonesia adalah aplikasi pembayaran. Salah satu contoh perusahan FinTech yang menyediakan aplikasi pembayaran, sebagai pengganti nilai mata uang adalah Go-Pay. Go-Pay merupakan jasa pembayaran virtual yang terdapat pada aplikasi Go-Jek. Sebelumnya, aplikasi ini menjadi hanya sebagai alat pembayaran pada transportasi Go-Jek saja. Saat ini Go-Pay sudah menambah layanan baru, yang dapat digunakan pada transaksi pembayaran virtual di restoran dan tempat belanja lainnya.

Fintech menjadi sangat penting dan membantu mengerakkan roda perekonomian yang produktif serta dapat mengembangkan Usaha kecil Menengah. Hal ini terbukti dari data yang terdapat di laman GoJek. Pada tahun 2018 terdapat lebih dari 420.000 rekan usaha yang dimiliki perusahan Gojek dan $90 \%$ rekan usaha tersebut merupakan pengusaha kecil yang telah menerapkan pembayaran dengan uang virtual. Artinya ada banyak manfaat yang dirasakan oleh pedagang kecil menegah dengan kehadiran uang virtual ini.

Uang virtual pada dasarnya merupakan jenis uang tanpa adanya fisik, dimana nilai uangnya berasal dari nilai uang rill yang disetorkan dahulu kepada penerbitnya, disimpan secara elektronik dalam media elektronik berupa server based dan berfungsi sebagai alat pembayaran (Usman, 2017)

Bank Indonesia mendukung adanya transaksi uang virtual, berdasarkan Peraturan Bank Indonesia Nomor 11/12/PBI/2009 dan Nomor 16/8/PBI/2014 yang bertujuan untuk mengurangi peredaran uang tunai di Indonesia dan terciptanya less cash society, yaitu terbentuknya komunitas masyarakat yang lebih menerapkan pembayaran dengan uang virtual dalam melakukan transaksi keuangannya. Dari segi efisiensi bagi pemerintah, bermanfaat untuk menekan anggaran yang dikeluarkan setiap tahunnya dalam mencetak uang. (Tazkiyyaturrohmah, 2018)

Penelitian terdahulu banyak membahas penggunaan transaksi GoPay dari sisi user atau pembeli saja, sedangkan dari sisi pedagang kecil menengah yang menerima pembayaran uang virtual, belum ada yang melakukan penelitian. Seperti penelitian yang dilakukan oleh (Huwaydi dkk, 2018) Penelitian ini dilakukan untuk menganalisa penggunaan dari layanan GoPay. Dari 646 data yang diolah ditemukan beberapa karakteristik, antarlain: Pengguna alat pembayaran GoPay terbanyak adalah berjenis kelamin perempuan dan transaksi pembelian yang sering digunakan adalah pembelian makanan.

Penelitian yang dilakukan oleh (Bothun dkk, 2013) juga meneliti dari sisi pembeli, hasil penelitian didapatkan beberapa keuntungan yang membuat masyarakat tertarik untuk menggunakan alat pembayaran uang virtual. Keuntungan pertama adalah dapat berhemat. Perusahaan penerbit alat pembayaran virtual banyak memberikan promosi berupa diskon terhadap pengguna. Keuntungan kedua adalah kemudahan dalam bertransaksi. Pengguna uang virtual lebih praktis, cukup dengan handphone dan jaringan internet mereka sudah bisa melakukan transaksi pembayaran dan tanpa perlu membawa uang rill untuk melakukan transaksi pembayaran.

Dari latar belakang di atas, maka peneliti bermaksud meneliti dampak perubahan transaksi pembayaran virtual dari sisi pelaku usaha, khusunya pedagang kecil. Tujuan penelitian, anataralain yaitu : Apakah yang membuat pedagang kecil menengah selaku mitra GoPay tertarik menerima pembayaran dengan uang virtual (GoPay)? 2. Bagaimana pengaruh dari pembayaran uang virtual terhadap tingkat penjualan pedagang kecil menengah?

\section{Transaksi Pembayaran}

Sistem Pembayaran adalah suatu sistem yang mengatur kesepakatan, perjanjian, fasilitas operasional, mekanisme teknis, standar dan prosedur dalam suatu kerangka yang digunakan untuk penyampaian, pengesahan dan penerimaan instruksi pembayaran serta pemenuhan kewajiban pembayaran melalui pertukaran suatu nilai mata uang antar pihak perorangan dan lembaga lainnya dengan menggunakan instrumen pembayaran. Secara umum, contoh alat pembayaran yang selama ini telah kita kenal adalah uang, kartu debit, kartu kredit, traveller's cheque, serta alat pembayaran elektronik seperti internet banking, transfer kredit melalui kliring dan sebagainya (https://www.bi.go.id/id/edukasi-perlindungan-

konsumen/).

Transaksi pembayaran dalam transaksi virtual yang dilakukan para pebisnis untuk memfasilitasi bagi pemebeli dengan menyediakan layanan pembayaran online adalah sebagai berikut (Lowry, Paul Benjamin, et all, 2006):

1.Meningkatkan efisiensi cash flow

2.Transaksi yang terjamin.

3.Biaya operasional yang lebih hemat.

\section{Transaksi Pembayaran GoPay}

Diambil dari situs [https://www.gojek.com/] GoPay adalah uang virtual atau dompet digital berupa saldo yang dapat digunakan sebagai alat pembayaran dari berbagai layanan GoJek. Sejak Mei 2018, GoPay menghadirkan layanan baru, yang memungkinkan pengguna aplikasi GoJek untuk melakukan transaksi pembayaran selain yang ada pada layanan aplikasi GoJek. Alat pembayaran Gopay ini dapat digunakan di semua mitra yang berkerjasama dengan GoJek. Saat ini ada 420.000 mitra yang tergabung bersama GoJek. Salah satu cara untuk memperkenalkan penggunaan GoPay ke 
masyarakat, GoJek memberikan beragam jenis promo. Salah satu promo yang diberikan adalah diskon dan cashback bagi para pengguna.

Hampir semua toko dan pedagang kecil saat ini, sudah menggunakan uang digital sebagai alat pembayaran. Penerapan sistem cashless payment ini memperbarui sistem pembayaran tunai konvensional yang sudah dikenal. Indonesia dengan populasi generasi milenial terbanyak menurut data BPS, akan menjadi leader dalam penggunaan transaksi nontunai nantinya.

\section{Peningkatan Penjualan}

Menurut (Soemarso, 2003), Penjualan merupakan suatu proses pertukaran barang atau jasa antara penjual dengan pembeli. Didalam perekonomian kita, seseorang yang menjual sesuatu akan mendapatkan imbalan berupa uang. Dengan alat penukar berupa uang, orang akan lebih mudah memenuhi segala kebutuhan.Tujuan dari adanya penjualan, antaralain yaitu:untuk mendapatkan laba, mempertahankan usaha atau berusaha meningkatkan usaha untuk jangka waktu lama. Tujuan tersebut dapat direalisir apabila penjualan dapat dilaksanakan sesuai dengan yang direncanakan.

Aktivitas peningkatan penjualan banyak dipengaruhi oleh beberapa faktor, penjual perlu memperhatikan faktor-faktor yang mempengaruhi peningkatan penjualan. Menurut (Basu, 2005) sebagai berikut :

1) Kondisi dan Kemampuan Penjual

Penjual harus memahami beberapa masalah penting yang berkaitan dengan produk yang akan dijual, jumlah dan sifat dari barang/jasa yang akan ditawarkan

2) Kondisi Pasar

Pasar adalah sekelompok pembeli yang menjadi sasaran atau target penjualan. Yang harus diperhatikan oleh penjual adalah kondisi dan kebutuhan dari pasar.

3) Modal

Modal atau dana sangat diperlukan dalam mencapai target penjualan. Dalam melaksanaan kegiatan penjualan akan sangat sulit, jika pembeli belum mengenal produk kita. Kondisi seperti ini memerlukan modal usaha untuk mendukung kegiatan penjualan, seperti membeli kendaraan, menyewa tempat usaha dan membayar biaya iklan.

4) Kondisi Organisasi Perusahaan

Kondisi organisasi perusahan akan mempengaruhi tingkat penjualan. Masalah penjualan pada perusahan berskala besar biasanya ditangani oleh bagian khusus yang memahami penjualan dengan baik. Untuk perusahan berskala kecil, masalah penjualan ditangani oleh bagian yang juga melakukan tugas-tugas lainnya.

5) Faktor-faktor lain
Faktor-faktor lain seperti pemberian diskon dan bergabung dengan komunitas pengusaha juga dapat mempengaruhi penjualan.

\section{METODE PENELITIAN}

Metode penelitian ini adalah kualitatif dan mengunakan analisa data kualitatif deskriptif. Menurut (Creswell, 2012) penelitian kualitatif adalah sebuah metode untuk membangun makna fenomena berdasarkan pandangan-pandangan dari responden.

Menurut (Meleong, 2006) Penelitian kualitatif merupakan penelitian yang menghasilkan penemuan. Penelitian dilakukan dengan cara tidak menggunakan prosedur statistik.

Metode kualitatif dipilih oleh peneliti karena sesuai dengan tujuan penelitian ini, yang bermaksud menjelaskan dampak dari transaksi penggunaan GoPay bagi peningkatan penjualan dan tidak mencari hubungan antar variabel.

Lokasi penelitian berada di Pasar Modern BSD, Tangerang Selatan. Pemilihan lokasi ini diambil dikarenakan sebagai area penggunaan transaksi pembayaran Go-Pay terbanyak sehingga dapat memberikan gambaran terhadap penelitian ini. Objek penelitian adalah pedagang kecil menengah yang menggunakan pembayaran transaksi GoPay. Teknik pengumpulan data dilakukan dengan wawancara langsung dengan pedagang kecil menengah yang mengunakan pembayaran uang virtual, observasi dan dokumentasi. Sumber data untuk penelitian ini adalah data primer dan data sekunder. Data primer merupakan data yang langsung dikumpulkan pada saat melakukan penelitian yaitu berupa rekaman wawancara dan observasi langsung, sedangkan data sekunder didapat dari dokumentasi. Pengumpulan data wawancara melibatkan empat informan. Informan dalam penelitian ini adalah para pedagang kecil menengah di area pasar moden BSD. Penentuan informan dalam penelitian ini dilakukan dengan menggunakan teknik purposive sampling. Purposive sampling merupakan teknik menentukan sampel dengan mengunakan pertimbangan beberapa hal (Sugiono, 2009). Dalam memilih informan tersebut dilakukan dengan menentukan kriteria sebagai berikut:

1. Pedagamg kecil menengah, baik itu pedagang sayur atau pedagang grosir yang menjadi mitra GoPay

2. Durasi lama menjadi mitra GoPay lebih dari satu tahun

3. Berlokasi dagang di area Pasar modern BSD

Langkah-langkah yang peneliti lakukan, antaralain yaitu:

1.Membuat pedoman wawancara.

2.Memilih informan

3.Pengumpulan data

4.Intisari data

5.Penyajian data 
6.Kesimpulan

\section{Kerangka Konseptual}

Berdasarkan kajian pustaka dan penelitian terdahulu, maka kerangka konseptual dalam penelitian ini, sebagai berikut:

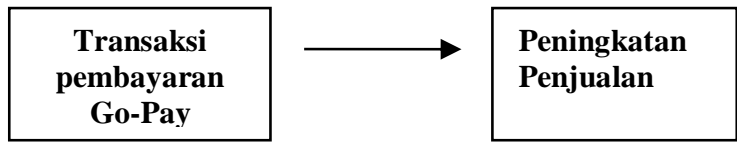

Gambar 1. Kerangka Pemikiran

\section{HASIL DAN PEMBAHASAN}

Penelitian ini dilakukan di area pasar modern BSD Tangerang Selatan, selama kurang lebih empat bulan. Pada bagian ini akan ditampilkan data primer berupa hasil wawancara langsung dengan para informan, berikut ini adalah data informan: pak asep, bu ginting, bu kezia dan pak anton.

Dalam penelitian ini terdapat dua rumusan masalah yang peneliti buat terkait dampak transaksi pembayaran GoPay terhadap peningkatan penjualan yang dirasakan oleh para pedang kecil menengah.

\section{Ketertarikan Pedagang kecil menengah menggunakan transaksi pembayaran GoPay}

Berikut adalah hasil wawancara untuk menjawab rumusan masalah pertama yaitu tentang Ketertarikan menggunakan transaksi pembayaran GoPay.

a. Informan pertama adalah seorang laki-laki yang sudah berdagang buah di pasar modern BSD sejak tahun 2018, dari hasil wawancara mengatakan bahwa yang membuat beliau tertarik mengunakan GoPay sebagai alat pembayaran dikarenakan kepraktisan, agar tidak repot mancari uang kembalian dan beliau dapat melakukan kegiatan lain membersihkan buah sambil melayani pembeli.

b. Informan kedua dalam penelitian ini adalah bu ginting, beliau berdagang ikan asin di pasar modern BSD. Beliau sudah mengunakan pembayaran uang virtual GoPay sejak tahun 2015, di saat aplikasi GoPay mulai hadir. Pada saat itulah bu ginting mendaftarkan diri untuk menjadi mitra GoPay. Ketertarikan menggunakan alat pembayaran uang virtual dikarenakan pada keinginannya untuk mengikuti selera pasar atau perkembangan zaman. Karena menurut beliau, umumnya pembeli yang datang ke pasar adalah orang-orang yang sibuk dan jarang membawa uang tunai, sebagaian dari pembeli banyak yang menanyakan pembayaran uang virtual.

c. Informan ketiga dalam penelitian ini adalah bu kezia, pedagang cabe dan bawang. Ibu kezia mengungkapkan bahwa beliau tertarik mengunakan alat pembayaran Go-Pay dikarenakan kebutuhan. Pembeli banyak yang menanyakan pembayaran uang virtual, agar dapat cashback dan potongan harga.

d. Informan keempat dalam penelitian ini adalah anton, pedagang kue pukis. Faktor yang menyebabkan pak anton ingin mengunakan alat pembayaran uang virtual adalah karena Untuk memenuhi permintaan pembeli, karena banyak pembeli yang jarang membawa uang kas.

Dari pernyataan-pernyataan informan diatas, peneliti dapat menarik kesimpulan bahwa alasan pedagang kaki kecil menerima pembayaran dengan uang virtual dikarenakan faktor kebutuhan masyarakat modern yang menginginkan kepraktisan dan memanfaatkan cashback yang diberikan oleh perusahan Go-Pay. Hal ini senada dengan penelitian (Genady, 2018) bahwa kemudahan uang virtual, kemanfaatan berupa diskon yang diberikan perusahan penyedia uang virtual berpengaruh terhadap keputusan penggunaan uang virtual di masyarakat. Atas hal diatas, maka pedagang kecil menengah harus bergerak cepat mengikuti perkembangan zaman dengan sistem pembayaran virtual, agar memudahkan para pedagang kecil dalam bertransaksi dengan pembeli .

Pengaruh pembayaran uang virtual terhadap tingkat penjualan pedagang kecil menengah

Berikut adalah jawaban pengaruh dari pembayaran uang virtual terhadap tingkat penjualan pedagang kecil menengah?

Semakin banyak konsumen yang datang untuk membeli buahnya, setelah mengunakan alat pembayaran uang virtual (asep).

a. Penjualan yang diterima dari pedagang ikan asin, bu ginting selama menggunakan alat pembayaran uang virtual GoPay mengalami peningkatan (Ginting)

b. Penjualan yang diterima dari hasil dagangan.

c. Kenaikan penjualan per hari rata-rata sebesar Rp.1.500.000 yang semula Rp.1.000.000 perhari.

d. Dari penjelasan para pedang kecil menengah berkaitan dengan peningkatan cabe dan bawang bu kezia mengalami peningkatan secara signifikan yaitu meningkat lebih dari $100 \%$ bila dibandingkan saat sebelum menggunakan alat pembayaran GoPay. Penjualan yang diperoleh yaitu sebesar Rp.1.500.000/hari Dimana sebelumnya hanya Rp.700.000/hari (kezia)

Kenaikan penjualan kue pukis pak anton selama menggunakan alat pembayaran virtual Go-Pay mengalami peningkatan penjualan yang diperolehnya dapat disimpulkan bahwa mereka menyatakan adanya kenaikan penjualan setelah menggunakan alat pembayaran uang virtual GoPay. Hal ini senada dengan pernyataan dari (Basu, 2005) bahwa Promosi berpengaruh terhadap kenaikan penjualan. Promosi yang diberikan perusahan GoPay berupa cashback 
dan discount menjadi daya tarik pembeli untuk berbelanja di toko tersebut.

\section{KESIMPULAN}

Berdasarkan hasil dan pembahasan diatas maka dapat ditarik beberapa kesimpulan. Pertama, FinTech di Indonesia memiliki beberapa layanan dan produk yang dapat dimanfaatkan oleh masyarakat. Bank Indonesia membaginya menjadi beberapa jenis, diantaranya yaitu seperti pinjaman atau kredit, gadai, sistem pembayaran, platform online untuk mengumpulkan donasi dan bantuan, perencanaan keuangan, pasar modal, layanan internet banking dan asuransi. Salah satu contoh perusahan FinTech dari jenis pembayaran yang ada di Indonesia adalah GoPay. GoPay merupakan layanan yang dimiliki oleh aplikasi GoJek, dahulu menjadi alat pembayaran transportasi online, saat ini GoJek, menambah layanan baru yaitu uang virtual yang dapat digunakan pada transaksi pembayaran di restoran dan tempat belanja lainnya. Kedua, Penelitian terdahulu banyak membahas penggunaan transaksi GoPay dari sisi user atau konsumen saja, sedangkan dari sisi pengusaha kecil menengah sebagai mitra dari GoPay belum ada yang melakukan penelitian. Ketiga, Alasan pedagang kaki kecil menerima pembayaran dengan uang virtual dikarenakan faktor kebutuhan masyarakat modern yang menginginkan kepraktisan dan memanfaatkan cashback yang diberikan oleh perusahan GoPay. Keeempat, berkaitan dengan peningkatan penjualan yang diperolehnya, para pedagang menyatakan adanya kenaikan penjualan setelah menggunakan alat pembayaran uang virtual GoPay. kelima, bagi peneliti selanjutnya, penelitian ini dapat sebagai referensi dengan menambahkan informan agar penelitian lebih berkembang.

\section{REFERENSI}

Basu, S. (2005). Manajemen Penjualan. BPFE.

Creswell, J. . (2012). Research Design Pendekatan Kualitatif Kuantitatif dan Mixed. Pustaka Pelajar.

D. Bothun, S. Glisson, R. Haas, C. Isaac, and M. L. (2013). "Consumer intelligence series;opening the mobile wallet,." , 'PricewaterhouseCoopers LLP.

Genady, D. I. (2018). Pengaruh Kemudahan, Kemanfaatan, Dan Promosi Uang Elektronik Terhadap Keputusan Penggunaan Uang Elektronik Di Masyarakat (Studi Kasus di Provinsi DKI Jakarta). Skripsi, 11140850000042.

https://www.bi.go.id/id/edukasi-perlindungankonsumen/edukasi/produk-dan-jasasp/fintech/Pages/default.aspx. (n.d.).

https://www.gojek.com/blog/gofood/cara-menjadimerchant-go-pay/. (n.d.).

Huwaydi, Y., Hakim, M, S., dan Persada, S. F. (2018). Analisis Deskriptif Pengguna Go-Pay di Surabaya. JURNAL TEKNIK ITS Vol. 7, No. 1 (2018) 2337-3520 (2301-928X Print), 7(1), $1-5$.

Lowry, Paul Benjamin, et all. (2006). Online Payment Gateways Used to Facilitate E-commerce Transactions and Improve Risk Management. CAIS, Vol 17.

Meleong, L. J. (2006). Metodelogi Penelitian Kualitatif. Remaja Rosdakarya.

Soemarso. (2003). Akuntansi Suatu Pengantar. Salemba Empat.

Sugiono. (2009). Metode Penelitian Kuantitatif. Bayu Indra Grafika.

Tazkiyyaturrohmah, R. (2018). Transaksi Keuangan Modern. Eksistensi Uang Elektronik Sebagai Alat Transaksi Keuangan Modern, $d$ (November 2016), 21-39.

Usman, R. (2017). Karakteristik Uang Elektronik Dalam Sistem Pembayaran. Yuridika, 32(1), 134. https://doi.org/10.20473/ydk.v32i1.4431 